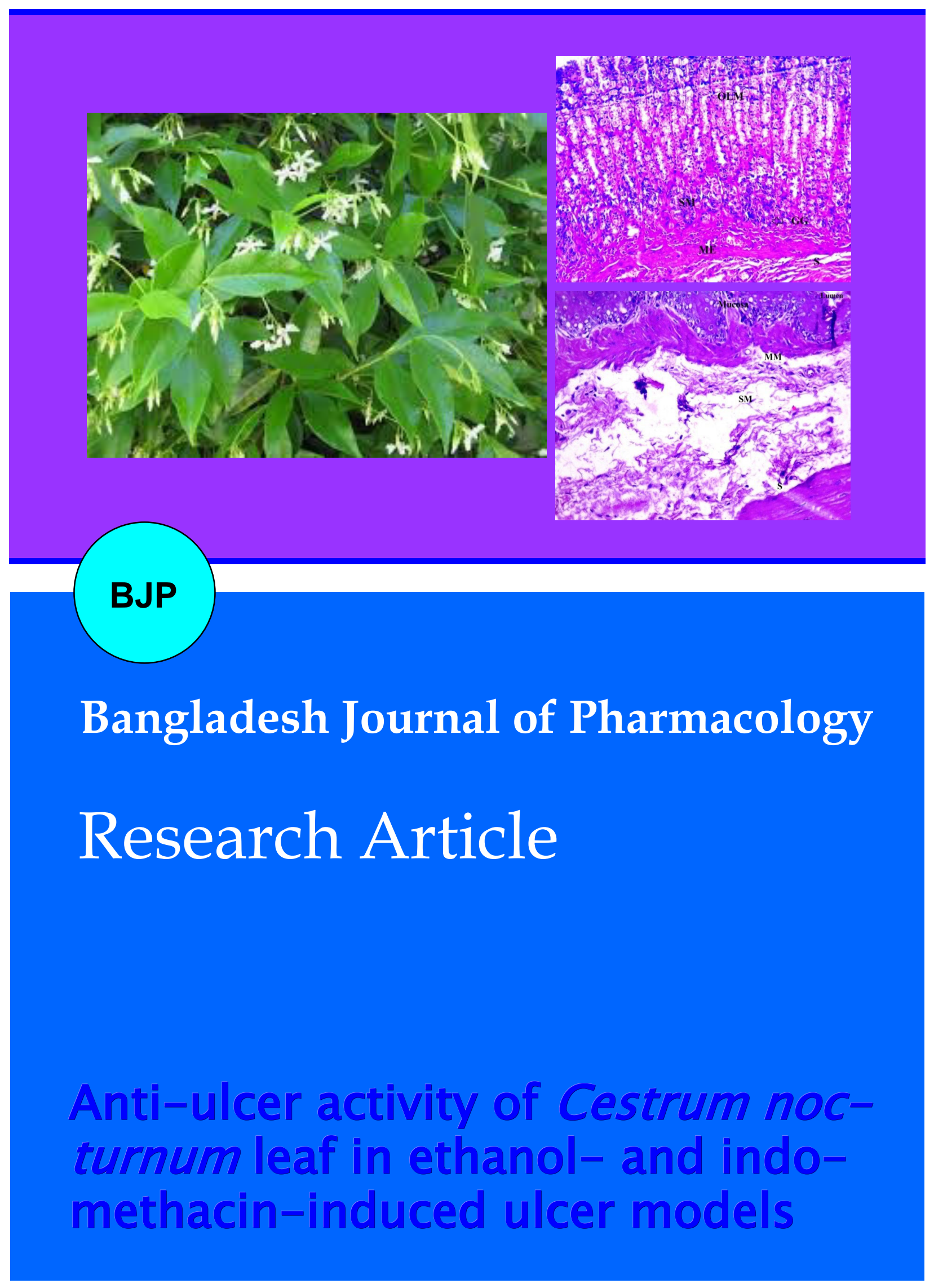


Abstracted/indexed in Academic Search Complete, Asia Journals Online, Bangladesh Journals Online, Biological Abstracts, BIOSIS Previews, CAB Abstracts, Current Abstracts, Directory of Open Access Journals, EMBASE/Excerpta Medica, Global Health, Google Scholar, HINARI (WHO), International Pharmaceutical Abstracts, Open J-gate, Science Citation Index Expanded, SCOPUS and Social Sciences Citation Index;

ISSN: $1991-0088$

\title{
Anti-ulcer activity of Cestrum nocturnum leaf in ethanol- and indomethacin-induced ulcer models
}

\author{
Uzma Saleem', Ejaz ul Haq1, Bashir Ahmad² and Mohammad Saleem¹ \\ ${ }^{1}$ Faculty of Pharmaceutical Sciences, Government College University, Faisalabad, Pakistan; ${ }^{2}$ Riphah Institute of \\ Pharmaceutical Sciences, Riphah International University, Lahore Campus, Lahore, Pakistan.
}

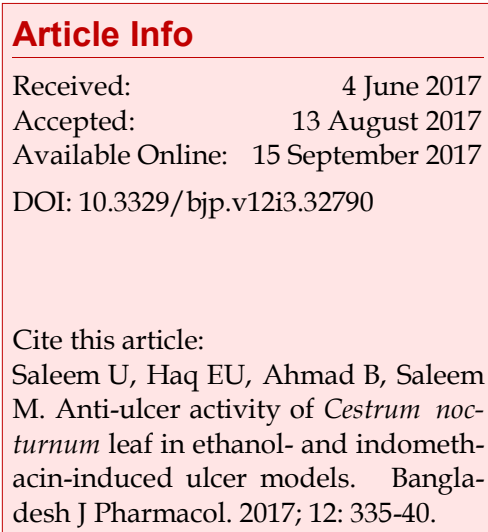

\section{Introduction}

In clinical practice peptic ulcer is the most common gastrointestinal disorder (Bafna and Balaraman, 2004). In such cases both synthetic and herbal medication are better and newer option for management and treatment of peptic ulcer disease (Dharmani et al., 2005). The patho-physiological causes of gastric ulcer were not completely defined but reasons behind ulcer are imbalance between the physiological and aggressive factors (pepsin and acid secretion) and gastric mucus membrane cytoprotective factors (bicarbonates and mucus secretion). Several endogenous factors of ulcer protection are also involved, which includes somatostatin, prostaglandins $E_{2}$, sulfhydryl compounds and nitric oxide (de Sousa Araújo et al., 2008). Commercially available, antacids, $\mathrm{H}_{2}$ blockers, proton pump inhibitors are standard therapies for ulceration. But the use of these drugs is associated with number of side effects. WHO (1980) has suggested the research on natural products in those conditions where the use of synthetic drugs are not free from adverse effects. This recommendation creates a chance of discovering new therapeutic agents that are safe, less toxic and more efficacious in the treatment or prevention of ulcer from the community of medicinal plants.

Phyto-therapeutic agents are under limelight for the management and treatment of diseases globally (Cipriani et al., 2008; Gul et al., 2015). Number of plants have been investigated for anti-ulcer activity by number of researchers such as Mentha longifolia, Dalbergia sissoo, Morus nigra, Convolvulus arvensis and Chenopodium murale (Saleem et al., 2014; Mallhi et al., 2014; Ali et al., 2013; Gul et al., 2015; Gul et al., 2016).

Cestrum nocturnum belongs to solanaceae family with common name of "night blooming jasmine (Patil et al., 2011). It is perennial shrub and pollinated with the help of night flying insects and attracted by its fragrance (Sykorova et al., 2003).

Cestrum nocturnum is being used as folklore remedy for 
gastric ulcer. The present investigation was undertaken to provide scientific-based evidence to justify the folklore use as rational or irrational. Additionally the aim was to explore the cheap, easily available and having fewer side effects remedy for gastric ulcer.

\section{Materials and Methods}

\section{Laboratory animals}

Wistar albino rats between weights 150-200 g were purchased from University of Health Sciences-Lahore and accommodated at animal house of Faculty of Pharmaceutical Sciences Government College University Faisalabad, Pakistan. Rats were placed at the room temperature $22 \pm 2^{\circ} \mathrm{C}$ and $12 / 12$ period of light and dark with proper ventilation facility. The relative humidity 44 to $56 \%$ was maintained. Rats of different group were placed in different cages having wire bottom to avoid the coprophagy and to facilitate the accurate evaluation. Proceeding to the experimentation, for one week rats were acclimatized and given the standard diet and water ad libitum. The experiments were performed by the approval of Animal Ethics Committee of Government College University of Faisalabad, Pakistan.

\section{Collection and identification of plant}

Fresh leaves of C. nocturnum was collected from the botanical garden of University of Agriculture, Pakistan. The plant leaves were identified and authenticated by the taxonomist at the botany department of University of Agriculture, Pakistan. Leaves were separated, washed with water and dried under shade. Dried leaves were ground to fine powder.

\section{Preparation of extract}

C. nocturnum leaf extract was prepared by two methods: a) Maceration; b) Decoction.

\section{Maceration}

Leaves powder was soaked in methanol (1:4) for five days with vigorous shaking at regular time intervals. $n$ hexane extract of leaves was prepared similarly. Extract was filtered with Whatman filter paper No. 1 and excess of solvent was removed with rotary evaporator.

\section{Decoction}

Freshly taken leaves of $C$. nocturnum (150 g) were boiled in one liter of water for the five minutes. Then decoction was allowed to cool for the $30 \mathrm{~min}$ and filtered through the Whatman filter paper No. 1. A fresh decoction was prepared after every three days.

\section{Study design}

Two ulcer models were used in this study which is as follows:

\section{Ethanol-induced gastric ulcer model}

The rats were separated into four groups, then group IV sub-divided into seven sub-groups, each of contain five animals and kept on fasting for the 24 hours with water ad libitum. Group I normal control received normal saline according to weight, Group II disease control, Group III standard control treaded with omeprazole (20 $\mathrm{mg} / \mathrm{kg}$, orally), Group IV (A, B, C ,D ,E, F and G) treated control administered methanolic and $n$-hexane extracts at doses $300,500,700 \mathrm{mg} / \mathrm{kg}$, orally, decoction at dose $(10 \mathrm{~mL} / \mathrm{kg}$, orally). After one hour dosing, ulcer was induced by administering ethanol (1 $\mathrm{mL} / \mathrm{kg}$, orally) to all groups except normal control. Animals were sacrificed by cervical dislocation, one hour after the administration of ethanol. Rats stomachs were removed, opened along the greater curvature, pinned on the soft board and stomach lesions were evaluated to determine the ulcer score.

\section{Indomethacin-induce gastric ulcer model}

The rats were separated into four group, then group IV sub-divided in seven sub-groups, each group contain five animals $(n=5)$ and kept on fasting for 24 hours with water ad libitum before study. Group I normal control, Group II disease control, Group III standard control received omeprazole (20 $\mathrm{mg} / \mathrm{kg}$, orally), Group IV (A, B, C, D, E, F and G) treated with methanolic and nhexane extracts at doses 300,500 and $700 \mathrm{mg} / \mathrm{kg}$, orally respectively and decoction at dose $(10 \mathrm{~mL} / \mathrm{kg}$, orally). After one hour dosing, ulcer was induced by administration of indomethacin $(30 \mathrm{mg} / \mathrm{kg}$, orally) to all animals except normal control animal. Animals were sacrificed by cervical dislocation, one hour after administration of indomethacin. Rat stomachs were removed, opened along the greater curvature, pinned on the soft board and stomach lesions were evaluated to determine the ulcer score.

\section{Ulcer index calculation}

The number of ulcers was counted by using the magnifying glass. Severity scores (Nwidu and Nwafor, 2009; Patidar, 2011)are as follows:

\begin{tabular}{lc|}
\hline Condition of stomach & Ulcer score \\
\hline Normal coloration & 0 \\
Spot hemorrhage & 0.5 \\
Ulcer spots more than two & 1.0 \\
Ulcer lesions $<3 \mathrm{~mm}$ & 2.0 \\
Ulcer covers more than 50\% of stom- & 3.0 \\
ach area & \\
Lesions on $80 \%$ area & 4.0 \\
Perforations & 5.0 \\
\hline & \\
Ulcer index (UI) $=\frac{\text { Ulcer score }}{\text { 10 }}$ & \\
Anti-ulcer activity (\%) calculation
\end{tabular}


Anti-ulcer activity(\%) / percentage protection is calculated by using following formula (Bhardwaj et al., 2012):

$$
\text { Anti }- \text { ulcer activity }=\frac{\text { UI (disease control })- \text { UI (Treated) }}{\text { UI (disease control) }} * 100
$$

Gastric volume, $\mathrm{pH}$ and acidity were determined by adopting Reignier et al., 2013, Delgado-Aros et al., 2002 and Segal et al., 1950 methods respectively.

\section{Histopathological evaluation of gastric tissues}

The wall of sacrificed rat stomach was fixed in $10 \%$ formalin and then paraffin blocks were made. Five micrometer thick section was cut from the paraffin block and stained with hematoxylin and eosin. Histopathological evaluations were carried out on the collected gastric tissue samples according to the method as reported elsewhere (Yu et al., 2015).

\section{Statistical analysis}

One-way ANOVA followed by Dunnett's posthoc by using GraphPad Prism version 5 was used for statistical analysis. Data were presented as mean \pm SEM. $p \leq 0.05$ was taken as statistically significant value.

\section{Results}

Ulcer score, ulcer index and anti-ulcer activity (\%) for ethanol- and indomethacin-induced ulcer models are given in Table I. In ethanol-induced ulcer models, there was dose-dependent increase in anti-ulcer activity in all treated groups. Methanol and $n$-hexane extract (700 $\mathrm{mg} / \mathrm{kg}$ ) showed $81 \%$ anti-ulcer activity which was higher than the standard value i.e. $75 \%$. Decoction showed only $56 \%$ anti-ulcer activity. Indomethacininduced ulcer model also showed identical results.

Table II shows the effect of extracts on the gastric $\mathrm{pH}$, acidity and juice. In both ethanol- and indomethacininduced ulcer models, both extracts at doses 300, 500, $700 \mathrm{mg} / \mathrm{kg}$, orally, leaves decoction $10 \mathrm{~mL} / \mathrm{kg}$, orally and standard drug $20 \mathrm{mg} / \mathrm{kg}$, orally significantly $(p \leq 0.05)$ reduced the free acidity, total acidity and volume of gastric juice but significantly increased the $\mathrm{pH}$ of gastric volume in a dose-dependent manner when compared with the disease control group.

\section{Histopathological evaluation}

Histopathological assessment of the tissues of gastric mucosa of rats had also established the fact that

Table I

Ulcer score, ulcer index and anti-ulcer activity of Cestrum nocturnum extracts

\begin{tabular}{|c|c|c|c|c|c|}
\hline Groups & Treatment & Dose & Ulcer score & Ulcer index & $\begin{array}{l}\text { Anti-ulcer } \\
\text { activity (\%) }\end{array}$ \\
\hline Group I (Normal control) & Normal saline & $2 \mathrm{~mL} / \mathrm{kg}$ & & & \\
\hline \multirow[t]{2}{*}{ Group II (Disease control) } & Ethanol & $1 \mathrm{~mL} / \mathrm{kg}$ & $15.5 \pm 0.0$ & $1.6 \pm 0.0$ & $0.0 \pm 0.0$ \\
\hline & Indomethacin & $30 \mathrm{mg} / \mathrm{kg}$ & $14.5 \pm 0.0$ & $1.5 \pm 0.0$ & $0.0 \pm 0.0$ \\
\hline Group III (Standard) & Omeprazole & $20 \mathrm{mg} / \mathrm{kg}$ & $3.5 \pm 0.2^{\mathrm{a}}$ & $0.4 \pm 0.0^{\mathrm{a}}$ & $75 \pm 4.1^{\mathrm{a}}$ \\
\hline \multirow{7}{*}{$\begin{array}{l}\text { Group IV (Ethanol-induced ulcer } \\
\text { model) }\end{array}$} & Methanolic extract & $300 \mathrm{mg} / \mathrm{kg}$ & $5.6 \pm 0.5^{\mathrm{a}}$ & $0.6 \pm 0.1^{a}$ & $69 \pm 3.3^{a}$ \\
\hline & Methanolic extract & $500 \mathrm{mg} / \mathrm{kg}$ & $4.9 \pm 0.4^{a}$ & $0.5 \pm 0.0^{\mathrm{a}}$ & $71 \pm 1.6^{\mathrm{a}}$ \\
\hline & Methanolic extract & $700 \mathrm{mg} / \mathrm{kg}$ & $2.9 \pm 0.5^{\mathrm{a}}$ & $0.3 \pm 0.1^{a}$ & $81 \pm 3.4^{\mathrm{a}}$ \\
\hline & $n$-Hexane extract & $300 \mathrm{mg} / \mathrm{kg}$ & $4.9 \pm 0.4^{a}$ & $0.5 \pm 0.0^{\mathrm{a}}$ & $69 \pm 2.4^{\mathrm{a}}$ \\
\hline & $n$-Hexane extract & $500 \mathrm{mg} / \mathrm{kg}$ & $4.1 \pm 0.5^{a}$ & $0.4 \pm 0.1^{\mathrm{a}}$ & $75 \pm 3.2^{\mathrm{a}}$ \\
\hline & $n$-Hexane extract & $700 \mathrm{mg} / \mathrm{kg}$ & $2.6 \pm 0.4^{a}$ & $0.3 \pm 0.0^{a}$ & $81 \pm 2.4^{\mathrm{a}}$ \\
\hline & Decoction & $10 \mathrm{~mL} / \mathrm{kg}$ & $7.0 \pm 1.2^{\mathrm{a}}$ & $0.7 \pm 0.1^{\mathrm{a}}$ & $56 \pm 2.6^{\mathrm{a}}$ \\
\hline \multirow{7}{*}{$\begin{array}{l}\text { Group V (Indomethacin induce } \\
\text { ulcer model) }\end{array}$} & Methanolic extract & $300 \mathrm{mg} / \mathrm{kg}$ & $5.0 \pm 0.4^{a}$ & $0.5 \pm 0.0^{a}$ & $67 \pm 3.1^{\mathrm{a}}$ \\
\hline & Methanolic extract & $500 \mathrm{mg} / \mathrm{kg}$ & $4.5 \pm 0.5^{\mathrm{a}}$ & $0.4 \pm 0.1^{\mathrm{a}}$ & $73 \pm 3.2^{\mathrm{a}}$ \\
\hline & Methanolic extract & $700 \mathrm{mg} / \mathrm{kg}$ & $2.7 \pm 0.4^{a}$ & $0.3 \pm 0.0^{\mathrm{a}}$ & $80 \pm 2.6^{a}$ \\
\hline & $n$-Hexane extract & $300 \mathrm{mg} / \mathrm{kg}$ & $4.6 \pm 0.3^{a}$ & $0.5 \pm 0.0^{\mathrm{a}}$ & $67 \pm 2.3^{a}$ \\
\hline & $n$-Hexane extract & $500 \mathrm{mg} / \mathrm{kg}$ & $4.2 \pm 0.3^{a}$ & $0.4 \pm 0.0^{a}$ & $75 \pm 2.0 \mathrm{a}$ \\
\hline & $n$-Hexane extract & $700 \mathrm{mg} / \mathrm{kg}$ & $2.5 \pm 0.4^{a}$ & $0.2 \pm 0.0^{\mathrm{a}}$ & $80 \pm 2.2^{a}$ \\
\hline & Decoction & $10 \mathrm{~mL} / \mathrm{kg}$ & $5.6 \pm 0.5^{a}$ & $0.6 \pm 0.1^{a}$ & $60 \pm 3.9^{a}$ \\
\hline
\end{tabular}

Data represented as mean $\pm \mathrm{SEM} ; \mathrm{a}<0.05$ when compared with disease control; ns = non-significant when compared with disease control 
methanolic and $n$-hexane extracts of C. nocturnum leaves had shown significant anti-ulcer activity in a dose-dependent manner (Figure 1).

\section{Discussion}

Treatment groups in both ulcer models showed significant $(\mathrm{p}<0.05)$ anti-ulcer effect in methanol- and $n$ hexane-treated groups which is comparable to the effect of standard drug while decoction showed less protecttion of mucosal and epithelial cells against corrosive action of ethanol and indomethacin in stomach.

Histopathological analysis of gastric mucosa of treated rats showed dose-dependent anti-ulcer effect of both extracts whereas decoction could not protect gastric mucosa to the level that extracts did. This might be due to chemical constituents that were extracted in methanol and $n$-hexane extracts.

Banerjee and Firdous, (2015) studied Ipomoea staphylina hydroalcoholic extract for anti-ulcer activity to find out new anti-ulcer drug with less adverse effects as compared to currently available ulcer treatment medicines. This plant extract showed significant decrease in free acicidity, total acidity, and ulcer index which was supported by histopathological analysis. Current results are in agreement with Banerjee and Firdous findings (Banerjee and Firdous; 2015). Gul et al., (2015) explored anti-ulcer activity of Menthe longifolia and found decline in ulcer index (Gul et al., 2015). Dalbergia sissoo has been discovered to possess anti-ulcer activity by gastric mucosal protection (Gul et al., 2016). Our results are in accordance with the findings of studies conducted by Gul et al., 2015 and 2016.

Increased gastric juice secretion and decreased gastric $\mathrm{pH}$ lead to increase in acidity in stomach which if not treated at early stage may cause gastric ulceration. C. nocturnum leaves extracts showed anti-ulcer activity by decreasing lesions score, reducing gastric juice volume and acidity and increasing gastric $\mathrm{pH}$.

\section{Table II}

Effect of Cestrum nocturnum extracts on gastric juice $\mathrm{pH}$, volume and acidity

\begin{tabular}{|c|c|c|c|c|c|c|}
\hline Group & Treatment & Dose & $\begin{array}{l}\mathrm{pH} \text { of gas- } \\
\text { tric juice }\end{array}$ & $\begin{array}{r}\text { Volume of } \\
\text { gastric juice }\end{array}$ & $\begin{array}{l}\text { Free acidity } \\
(\mathrm{mEq} / \mathrm{L})\end{array}$ & $\begin{array}{r}\text { Total acidity } \\
(\mathrm{mEq} / \mathrm{L})\end{array}$ \\
\hline $\begin{array}{l}\text { Group I (Normal } \\
\text { control) }\end{array}$ & Normal saline & $2 \mathrm{~mL} / \mathrm{kg}$ & $2.0 \pm 0.1^{\mathrm{ns}}$ & $3.5 \pm 0.6^{a}$ & $40.5 \pm 2.9^{a}$ & $51.4 \pm 4.5^{\mathrm{a}}$ \\
\hline \multirow{2}{*}{$\begin{array}{l}\text { Group II (Disease } \\
\text { control) }\end{array}$} & Ethanol & $1 \mathrm{~mL} / \mathrm{kg}$ & $1.1 \pm 0.1$ & $4.3 \pm 0.1$ & $59.5 \pm 2.1$ & $68.4 \pm 3.5$ \\
\hline & Indomethacin & $30 \mathrm{mg} / \mathrm{kg}$ & $1.9 \pm 0.1$ & $4.1 \pm 0.7$ & $55.1 \pm 1.7$ & $61.4 \pm 5.7$ \\
\hline \multirow{4}{*}{$\begin{array}{l}\text { Group III } \\
\text { (Standard) }\end{array}$} & Omeprazole & $20 \mathrm{mg} / \mathrm{kg}$ & $4.7 \pm 0.2^{\mathrm{a}}$ & $2.0 \pm 0.1^{\mathrm{a}}$ & $13.8 \pm 3.1^{\mathrm{a}}$ & $28.2 \pm 4.6^{\mathrm{a}}$ \\
\hline & Methanolic extract & $300 \mathrm{mg} / \mathrm{kg}$ & $3.6 \pm 0.1^{a}$ & $2.5 \pm 0.1^{a}$ & $18.8 \pm 1.1^{\mathrm{a}}$ & $38.5 \pm 1.3^{a}$ \\
\hline & Methanolic extract & $500 \mathrm{mg} / \mathrm{kg}$ & $3.9 \pm 0.1^{\mathrm{a}}$ & $2.3 \pm 0.1^{\mathrm{a}}$ & $15.8 \pm 0.6^{\mathrm{a}}$ & $32.6 \pm 1.4^{\mathrm{a}}$ \\
\hline & Methanolic extract & $700 \mathrm{mg} / \mathrm{kg}$ & $4.9 \pm 0.3^{a}$ & $2.6 \pm 0.1^{a}$ & $12.8 \pm 1.3^{a}$ & $25.1 \pm 2.8^{a}$ \\
\hline \multirow{6}{*}{$\begin{array}{l}\text { Group IV (Ethanol- } \\
\text { induced ulcer } \\
\text { model) }\end{array}$} & $n$-Hexane extract & $300 \mathrm{mg} / \mathrm{kg}$ & $3.8 \pm 0.2^{\mathrm{a}}$ & $2.3 \pm 0.1^{a}$ & $17.2 \pm 1.1^{\mathrm{a}}$ & $35.9 \pm 1.6^{\mathrm{a}}$ \\
\hline & $n$-Hexane extract & $500 \mathrm{mg} / \mathrm{kg}$ & $4.4 \pm 0.3^{a}$ & $2.4 \pm 0.1^{a}$ & $15.1 \pm 1.0^{a}$ & $33.9 \pm 2.4^{a}$ \\
\hline & $n$-Hexane extract & $700 \mathrm{mg} / \mathrm{kg}$ & $5.4 \pm 0.2^{\mathrm{a}}$ & $2.1 \pm 0.1^{a}$ & $10.5 \pm 0.8^{\mathrm{a}}$ & $23.0 \pm 2.9 a$ \\
\hline & Decoction & $10 \mathrm{~mL} / \mathrm{kg}$ & $2.5 \pm 0.1^{a}$ & $3.4 \pm 0.1^{a}$ & $25.5 \pm 0.7 \mathrm{a}$ & $45.1 \pm 1.5^{a}$ \\
\hline & Methanolic extract & $300 \mathrm{mg} / \mathrm{kg}$ & $3.5 \pm 0.2^{\mathrm{a}}$ & $2.8 \pm 0.1^{a}$ & $18.2 \pm 1.4^{\mathrm{a}}$ & $38.4 \pm 3.2^{\mathrm{a}}$ \\
\hline & Methanolic extract & $500 \mathrm{mg} / \mathrm{kg}$ & $3.5 \pm 0.1^{a}$ & $2.6 \pm 0.1^{a}$ & $17.2 \pm 1.5^{\mathrm{a}}$ & $35.9 \pm 3.6^{a}$ \\
\hline \multirow{5}{*}{$\begin{array}{l}\text { Group V } \\
\text { (Indomethacin- } \\
\text { induced ulcer } \\
\text { model) }\end{array}$} & Methanolic extract & $700 \mathrm{mg} / \mathrm{kg}$ & $5.3 \pm 0.3^{a}$ & $2.4 \pm 0.1^{\mathrm{a}}$ & $10.9 \pm 1.1^{\mathrm{a}}$ & $23.0 \pm 2.1^{a}$ \\
\hline & $n$-Hexane extract & $300 \mathrm{mg} / \mathrm{kg}$ & $3.5 \pm 0.2^{\mathrm{a}}$ & $2.4 \pm 0.1^{a}$ & $17.9 \pm 1.3^{a}$ & $37.1 \pm 3.4^{\mathrm{a}}$ \\
\hline & $n$-Hexane extract & $500 \mathrm{mg} / \mathrm{kg}$ & $4.0 \pm 0.2^{a}$ & $2.6 \pm 0.1^{a}$ & $15.4 \pm 0.5^{\mathrm{a}}$ & $31.7 \pm 0.8^{a}$ \\
\hline & $n$-Hexane extract & $700 \mathrm{mg} / \mathrm{kg}$ & $5.3 \pm 0.3^{a}$ & $2.6 \pm 0.1^{a}$ & $9.8 \pm 1.9 a$ & $23.4 \pm 2.1^{\mathrm{a}}$ \\
\hline & Decoction & $10 \mathrm{~mL} / \mathrm{kg}$ & $3.7 \pm 0.1^{\mathrm{a}}$ & $3.0 \pm 0.04^{a}$ & $2.0 \pm 1.0^{a}$ & $38.8 \pm 1.4^{a}$ \\
\hline
\end{tabular}

Data were represented as mean $\pm \mathrm{SEM}$; ap $<0.05$ when compared with disease control; ns = non-significant when compared with disease control 

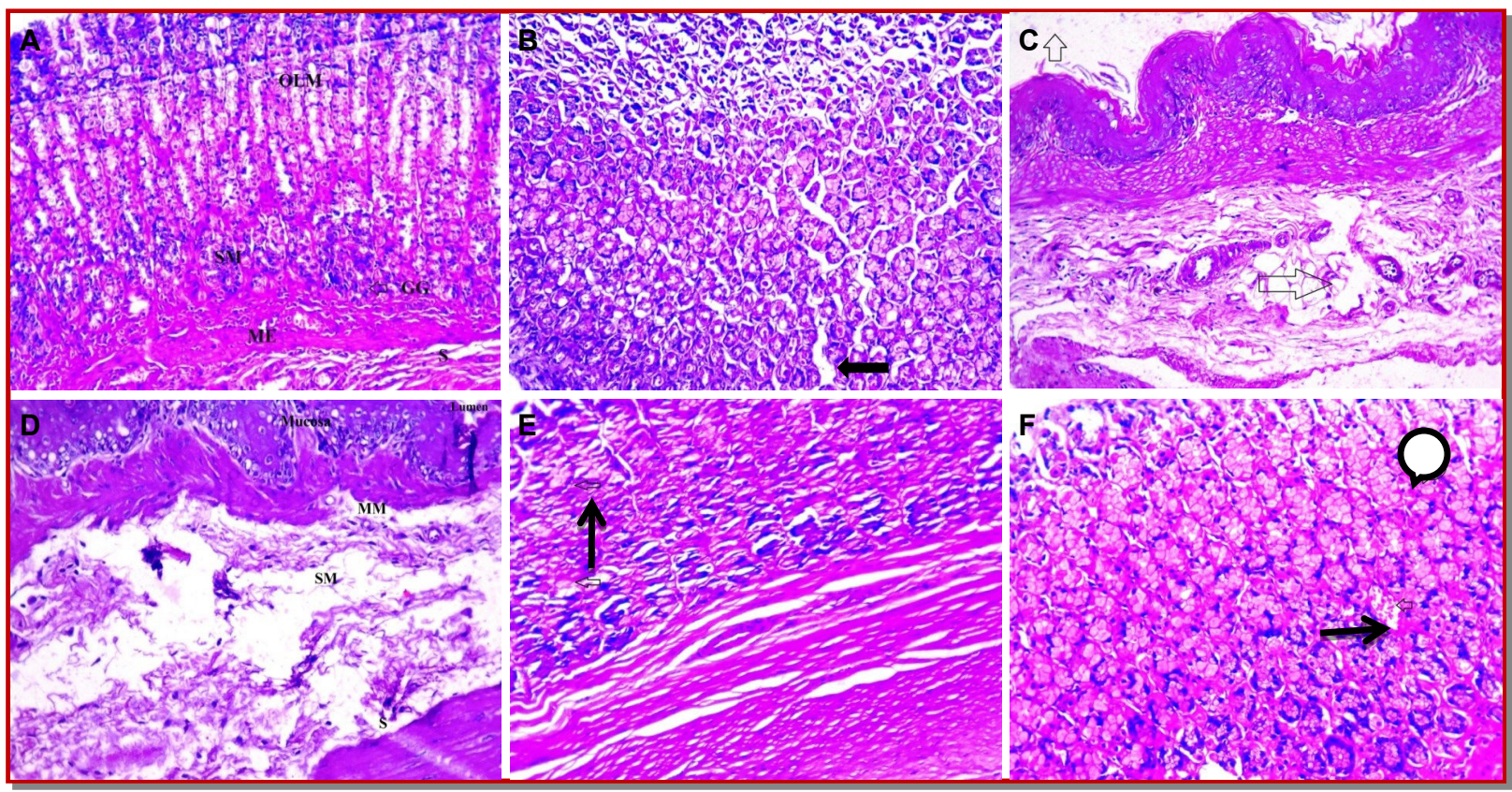

Figure 1: Histological examination of gastric ulcers; A: Photomicrograph of rat stomach section from the control group showing the histological structure of the normal submucosa (SM), gastric gland (GG), serosa (S), muscularis externa (ME), outer longitudinal muscle (OLM); B: Standard group (omeprazole) is showing normal appearance of Gland cell and sub mucosal cell; C: Disease control (Ethanol induce ulcer) is indicating mucosal and sub mucosal ulceration along with loss epithelium cells in gastric mucosa; D: Disease control group (Indomethacin) is showing stomach of the ulcer control animal showing a severe effect on the submucosa with erosion, edema, moderate leucocyte infiltration and cellular debris; E: Methanolic extract $750 \mathrm{mg} / \mathrm{kg}+$ ethanol treated group is showing normal muscularis mucosa (MM), Submucosa (SM) and blood in mucosa cells; F: $n$-hexane $750 \mathrm{mg}+$ ethanol treated group is indicating condensation of mucosa and clustering of RBC's in sub mucosal layer

\section{Conclusion}

Methanolic and $n$-hexane extracts of C. nocturnum leaves have anti-ulcer and anti-secretary activity against ethanol and indomethacin induced ulcer models.

\section{Conflict of Interest}

All authors have completed the ICMJE uniform disclosure form and declare no support from any organization for the submitted work.

\section{References}

Ali M, Qadir MI, Saleem M, Janbaz KH, Gul H, Hussain L, Ahmad B. Hepatoprotective potential of Convolvulus arvensis against paracetamol-induced hepatotoxicity. Bangladesh J Pharmacol. 2013; 8: 300-04.

Bafna P, Balaraman R. Anti-ulcer and anti-oxidant activity of DHC-1, a herbal formulation. J Ethnopharmacol. 2004; 90: $123-27$.

Banerjee A, Firdous SM. Antiulcer activity of hydroalcoholic extract of Ipomoea staphylina plant in rats. Bangladesh J Pharmacol. 2015; 10: 652-53.

Bhardwaj A, Kumar R, Dabasa V, Alam N. Evaluation of antiulcer activity of Citrullus lanatus seed extract in Wistar albino rats. Int J Pharm Pharm Sci. 2012; 4: 135-39.
Cipriani TR, Mellinger CG, de Souza LM, Baggio CH, Freitas CS, Marques MC, Gorin PAJ, Sassaki GL, Iacomini M. Acidic heteroxylans from medicinal plants and their anti-ulcer activity. Carbohydr Polym. 2008; 74: 274-78.

de Sousa Araújo TA, Alencar NL, de Amorim ELC, de Albuquerque UP. A new approach to study medicinal plants with tannins and flavonoids contents from the local knowledge. J Ethnopharmacol. 2008; 120: 72-80.

Delgado-Aros S, Kim DY, Burton DD, Thomforde GM, Stephens D, Brinkmann BH, Camilleri M. Effect of GLP-1 on gastric volume, emptying, maximum volume ingested, and postprandial symptoms in humans. Am J Physiol Gastroint Liver Physiol. 2002; 282: G424-31.

Dharmani P, Mishra PK, Maurya R, Chauhan VS, Palit G. Allophylus serratus: A plant with potential anti-ulcerogenic activity. J Ethnopharmacol. 2005; 99: 361-66.

Gul H, Abbas K, Qadir MI. Gastro-protective effect of ethanolic extract of Mentha longifolia in alcohol- and aspirin-induced gastric ulcer models. Bangladesh J Pharmacol. 2015; 10: 24145 .

Gul H, Saleem U, Ahmad B. Does Dalbergia sissoo leaves possess anti-ulcer activity: An experimental study in alcohol and aspirin induced ulcerative rat models. Bangladesh J Pharmacol. 2016; 2: 100-04.

Mallhi TH, Qadir MI, Khan YH, Ali M. Hepatoprotective activity of aqueous methanolic extract of Morus nigra against paracetamol-induced hepatotoxicity in mice. Bangladesh J Pharmacol. 2014; 9: 60-66. 
Nwidu LL, Nwafor PA. Gastroprotective effects of leaf extracts of Carpolobia lutea (polygalaceae) G. Don. in rats. Afr J Biotechnol. 2009; 8.

Patidar DK. Anti-ulcer activity of aqueous extract of Murraya koenigii in albino rats. Int J Pharma Bio Sci. 2011; 2: 524-29.

Patil CD, Patil SV, Salunke BK, Salunkhe RB. Bioefficacy of Plumbago zeylanica (Plumbaginaceae) and Cestrum nocturnum (Solanaceae) plant extracts against Aedes aegypti (Diptera: Culicide) and nontarget fish Poecilia reticulata. Parasitol Res. 2011; 108: 1253-63.

Reignier J, Mercier E, Le Gouge A, Boulain T, Desachy A, Bellec F, Quenot JP. Effect of not monitoring residual gastric volume on risk of ventilator-associated pneumonia in adults receiving mechanical ventilation and early enteral feeding: A randomized controlled trial. JAMA 2013; 309: 249-56.

Segal HL, Miller LL, Morton JJ. Determination of gastric acidity without intubation by use of cation exchange indicator compounds. Proc Soc Exp Biol Med. 1950; 74: 21820.

Saleem M, Ahmed B, Qadir MI, Rafiq M, Ahmad M, Ahmad B. Hepatoprotective effect of Chenopodium murale in mice. Bangladesh J Pharmacol. 2014; 9: 124-28.

Sykorova E, Lim KY, Chase MW, Knapp S, Leitch IJ, Leitch AR, Fajkus J. The absence of Arabidopsis-type telomeres in Cestrum and closely related genera Vestia and Sessea (Solanaceae): First evidence from eudicots. Plant J. 2003; 34: 283-91.

Yu Y, Jia TZ, Cai Q, Jiang N, Ma MY, Min DY, Yuan Y. Comparison of the anti-ulcer activity between the crude and bran-processed Atractylodes lancea in the rat model of gastric ulcer induced by acetic acid. J Ethnopharmacol. 2015; 160: 211-18. 